\title{
PENGEMBANGAN MEDIA PEMBELAJARAN KIMIA MENGGUNAKAN LABORATORIUM VIRTUAL BERBASIS SMARTPHONE ANDROID
}

\author{
${ }^{1}$ Fatahu, Maryce Agusthinus Walukou' ${ }^{2}$, Wa Ode Mulyana ${ }^{3}$, \\ Ekacahyana Mandasari ${ }^{4}$ \\ ${ }^{1,3,4}$ Program Studi Pendidikan Kimia FKIP, ${ }^{2}$ Program Studi Pendidikan Biologi \\ FKIP, Universitas Halu Oleo, Kendari
}

Corresponding author: fatahu@uho.ac.id

\begin{abstract}
ABSTRAK
Chemical learning has theoretical and practical learning activities. The results of the interview with the aliyah head of state 1 kendari that students lack readiness before entering the laboratory and the limitation of tools and practical materials. The purpose of this researchis an alternative solution to the limited learning resources of schools/madrassa which is the ease of performing services without time or conventional classes in a laboratory which is also limited in tools and practical materials. The study is conducted at madarteasra aliyah country 1 kendari. The research method used is research and development (R\&D): (1) potential and problems; (2) data collection; (3) product design; (4) validation of product design; (5) revise product design; (6) product trials are limited. Virtual lab applications tested with tests on 20 science-enhanced students for viewing activity and student response. Studies show that $85 \%$ of students are "strongly supported" and $15 \%$ "supported" against the study media of a virtual lab application.
\end{abstract}

Keywords: Practice, Reaction Rate, Virtual Lab

\section{PENDAHULUAN}

Pendidik di zaman informasi ini selayaknya mempunyai gaya mengajar sequential, sensing, dan visual. Pendidik seharusnya memposisikan siswa agar menjadi sosok pembelajar aktif, mudah belajar dengan mengamati dan menarik generalisasi berupa kesimpulan tentang apa yang sedang dipelajari. Maka, pembelajaran yang terlalu banyak menggunakan metode ceramah dan komunikasi satu arah serta terpusat kepada guru (teachercentered) tidak akan cocok dengan mereka (Chen et al., 2015).

Karakter dari generasi yang terlahir di era tahun 2000- an atau yang biasa disebut Generasi milenial atau Generasi $Z$ ini sangat peka terhadap teknologi informasi dan komunikasi, artinya mereka memiliki keunggulan kemampuan dalam pemanfaatan teknologi untuk mengembangkan pengetahuan. Potensi besar ini seharusnya dimanfaatkan secara 
maksimal oleh guru agar pembelajaran bisa dilaksanakan secara terarah dan efektif. Pengembangan media pembelajaran berbasis teknologi informasi adalah hal yang sangat disarankan. Media pembelajaran berbasis teknologi informasi berfungsi sebagai alat bantu fisik maupun nonfisik yang dapat digunakan sebagai perantara antara guru dan siswanya dalam memahami materi pelajaran secara lebih efektif dan efisien (Fiedler \& Haruvy, 2009; Morozov, et al., 2004; Ismail et al, 2016).

Kimia sebagai salah satu cabang ilmu pengetahuan alam memiliki ciri khas yang membedakan dengan ilmu lain yang serumpun. Kimia mempelajari materi ditinjau dari struktur, komposisi, fenomena reaksi- reaksi ketika terjadi perubahan materi dan energi yang menyertai perubahan itu (Gilbert et al., 2018). Pembelajaran kimia memiliki kegiatan pembelajaran teori dan praktikum, selain memerlukan suatu kerangka pembelajaran juga dibutuhkan suatu media pembelajaran sebagai pendukung pembelajaran kimia, terutama pada pembelajaran praktikum dibatasi pengalokasian waktu terhadap penjelasan materi ajar, pengarahan prosedur praktikum ataupun penarikan kesimpulan yang mempengaruhi proses pembelajaran dan tingkat pemahaman peserta didik terhadap materi pembelajaran kimia (Hikmah et al., 2017).
Praktikum merupakan salah satu kegiatan untuk memberikan pemahaman pada siswa mengenai suatu materi. Siswa dapat memahami dan menyelesaikan masalah terkait konsep yang diajarkan di kelas serta mendapatkan pemahaman yang mendalam melalui proses saintifik dalam kegiatan praktikum (Lang, 2012; Makransky, 2016). Praktikum memiliki kedudukan yang sangat penting untuk mendukung penjelasan teoritis yang ada dalam pembelajaran kimia (Kurbanoglu \& Akim, 2010). Berdasarkan

hasil

wawancara yang dilakukan terhadap Kepala Laboratorium Kimia Madrasah Aliyah Negeri 1 Kendari dan 5 orang perwakilan peserta didik, kendala yang terjadi pada praktikum umumnya adalah siswa kurang memiliki kesiapan sebelum memasuki laboratorium. Berkaitan dengan kesiapan siswa, hal ini terjadi karena siswa tidak mencari informasi terlebih dahulu terkait praktikum yang akan dilakukan, sehingga banyak waktu yang terbuang untuk menyiapkan siswa pada kegiatan pra-lab untuk praktikum. Guru harus menjelaskan mengenai cara memodelkan/ mensimulasikan penggunaan alat dan bahan terkait praktikum yang akan dilakukan, serta seringkali harus menjelaskan kembali konsep awal mengenai materi yang terkait. Hasil wawancara juga diperoleh informasi bahwa keterbatasan alat dan bahan menjadi kendala lain 
yang umum dalam pelaksanaan kegiatan praktikum kimia di sekolah.

Perkembangan ilmu pengetahuan dan teknologi terus mendorong berbagai upaya pembaruan untuk pemanfaatan hasil teknologi dalam proses belajar (Arsyad, 2014). Hal ini dapat ditunjukkan dengan pemanfaatan smartphone sebagai media pembelajaran karena siswa memiliki kecenderungan dalam memanfaatkan hasil pembaruan teknologi untuk menambah pengetahuan mereka dalam belajar (Huang, 2004).

Dewasa ini, hampir semua lapisan masyarakat termasuk siswa memilih menggunakan smartphone dengan sistem operasi android karena android merupakan platform yang ideal untuk menyebarkan materi pelajaran kepada siswa dalam bentuk aplikasi (Chao, 2012). Perkembangan teknologi yang mempengaruhi pola belajar siswa tersebut dapat direspon dengan pengembangan virtual lab untuk mengatasi permasalahan praktikum seperti disebutkan di atas. Virtual laboratory dapat dijalankan pada smartphone berbasis android sehingga mudah dibawa kemana saja dan tanpa memerlukan akses internet. Keunggulan ini dapat dimanfaatkan untuk memfasilitasi siswa dalam belajar guna meningkatkan pemahaman konsep pada aspek kognitif dan psikomotorik dalam pembelajaran kimia berbasis praktikum. Lebih spesifik, Mahanta \& Sarma (2012) menyarankan penggunaan Laboratorium Virtual (Lab-Vir) dengan memanfaatkan komputer untuk mensimulasikan sesuatu yang rumit, perangkat percobaan yang mahal atau mengganti percobaan di lingkungan berbahaya (Mahanta \& Sarma, 2012). Lebih jauh Martı'nez, et al., (2011) menandaskan bahwa Lab-Vir memungkinkan peserta didik dapat memvisualisasikan dan berinteraksi dengan fenomena yang akan mereka alami jika melakukan percobaan di laboratorium nyata (Martínez et al., 2011).

Materi yang digunakan dalam Laboratorium Virtual(LabVir) harus sesuai dengan kompetensi dasar yang terdapat dalam Permendikbud Nomor 59 Tahun 2014. Kompetensi dasar (KD) pengetahuan untuk materi laju reaksi adalah KD 3.7 yaitu Menganalisis faktor-faktor yang mempengaruhi laju reaksi dan menentukan orde reaksi berdasarkan data hasil percobaan, dan untuk keterampilannya adalah KD 4.7 yaitu Merancang, melakukan, dan menyimpulkan serta menyajikan hasil percobaan faktor-faktor yang mempengaruhi laju reaksi dan orde reaksi. Berdasarkan KD tersebut, maka perlu dilakukan praktikum materi laju reaksi khususnya pada materi faktorfaktor yang mempengaruhi laju reaksi. Dilihat dari kendala yang menyebabkan kegiatan praktikum tidak dilakukan sehingga 
pembelajaran berbasis virtual lab adalah solusi yang mungkin untuk dilakukan.

Berdasarkan latar belakang di atas maka perlu dilakukan pengembangan perangkat pembelajaran berbasis media Lab- Vir pada materi kimia laju reaksi. Hal ini dilakukan untuk dapat memaksimalkan proses pembelajaran. Diharapkan kegiatan pembelajaran tidak lagi terbatas pada penjelasan konsep semata. Secara umum penelitian ini bertujuan untuk memberikan alternatif solusi pada keterbatasan sumber daya pembelajaran di sekolah/madrasah, dengan memberikan kemudahan pada peserta didik untuk melakukan praktikum tanpa terikat waktu maupun kelas konvensional di laboratorium yang mempunyai keterbatasan jam praktikum dan alat, bahan sebagai sarana pembelajaran di laboratorium. Berdasarkan model Laboratorium Virtual yang dibuat dalam penelitian ini, dengan dilakukan secara online peserta didik bisa melakukan download materi, tutorial, maupun upload hasil tugas praktikum yang dikerjakan. Sistem yang dijalankan membuat Laboratorium seolah buka 24 jam kerja, praktikum dapat dilakukan kapan saja dengan access online (Bintaro \& Kusir, 2018).

Metode penelitian $R \& D$ digunakan untuk menghasilkan suatu produk tertentu (Sugiyono, 2015).

\section{METODE PENELITIAN}

Pengemabangan pada penelitian ini menghasilkan suatu produk. Penelitian dilaksanakan dilingkup Jurusan Pendidikan Kimia Universitas Halu Oleo dan Madarasah Aliyah Negeri 1 Kendari. Objek penelitian ini adalah perangkat media pembelajaran virtual lab. Perangkat media pembelajaran virtual lab dikembangkan dengan mengumpulkan berbagai informasi tentang kebutuhan yang berhubungan dengan produk yang akan dihasilkan sesuai dengan Kurikulum 2013.

Prosedur pengembangan pada penelitian $R \& D$ ini menggunakan model pengembangan Four-D Model (4D). Beberapa penjabaran tahapan dalam pengembangan model $4 D$ dalam penelitian ini:

\section{Define (Pendefinisian)}

Tahap pendefinisian dilakukan penetapan dan pendefinisikan syarat-syarat pembelajaran yaitu dengan melakukan observasi awal mengenai kondisisekolah. Pada tahap ini terdiri dari 6 langkah, yaitu analisis awal, analisis peserta didik, analisis tugas, analisis konsep, spesifikasi tujuan pembelajaran dan penyusunan instrumen penelitian.

\section{Design (Perancangan)} Merancang

modul berdasarkan hasil analisis kebutuhan pada tahap pendefinisian. Kegiatan yang dilakukan pada tahap pendesainan adalah pemilihan media, pemilihan 
format serta perancangan awal, terdiri dari tahap penyusunan draft produk dan penyusunan instrumen penilaian.

\section{Develop Pengembangan)}

Tahap

pengembangan bertujuan untuk menghasilkan bentuk akhir media pembelajaran setelah melalui revisi berdasarkan komentar, saran, dan penilaian dosen ahli dan data hasil uji coba. Tahap ini meliputi dua langkah, yaitu validasi desain dan uji coba terbatas.

Instrumen penelitian ini terdiri dari 2, yaitu:

\section{a. Instrumen validasi ahli}

Skala penilaian yang digunakan yaitu skala penilaian 1 sampai 3. Lembar penilaian tersebut meliputi tiga aspek kriteria yang ditentukan untuk validasi. Aspek kualitas media pembelajaran terdiri atas aspek rekayasa perangkat lunak, aspek komunikasi visual, aspek kesesuaian media dan materi serta aspek desain pembelajaran.

\section{b. Instrumen tanggapan} produk

Instrumen

tanggapan

terhadap produk berbentuk angket yang berisi pertanyaanpertanyaan dan kolom untuk menuliskan masukan atau saran untuk perbaikan yang akan diberikan oleh guru dan siswa.

Teknik pengumpulan data pada penelitian pendahuluan adalah pemberian angket terhadap 2 orang guru kimia dan 10 siswa kelas XII IPA. Angket yang digunakan pada penelitian ini berupa angket dengan jawaban tertutup yaitu jawaban sangat setuju (SS), setuju (S), kurang setuju (KR), dan tidak setuju (TS) serta ditanggapi dengan memberi saran pada kolom yang sudah tersedia. Pada penilaian aspek kualitas media pembelajaran menggunakan angket yang dilakukan oleh validasi ahli media dan ahli materi serta guru dan siswa.

Teknik analisis data pada penelitian ini dilakukan Analisis data hasil validasi tim ahli dilakukan dengan menggunakan 3 skor penilaian. Persentase hasil validasi dihitung dengan menggunakan persamaan sebagai berikut:

$$
X=\frac{\sum X}{N}
$$

Keterangan:

$X=$ Skor rata-rata penilaian oleh validator

$\Sigma X=$ Jumlah skor yang diperoleh validator

$\mathrm{N}=$ Jumlah data (Sugiono, 2010).

Data tentang instrumen penilaian kelayakan media pembelajaran virtual laboratory oleh ahli media dan ahli materi dengan memasukkan jawaban sesuai skornya dengan cara sebagai berikut:

Rentang = data terbesar - data terkecil $=3-1=2$

$$
\text { Setelah memperoleh }
$$

rentang, langkah selanjutnya adalah menentukan panjang interval kelas $(P)$ (Sudjana, 2005). 


$$
\begin{aligned}
& P=\frac{R}{K y d h e} \\
& =\frac{2}{3}=0,67
\end{aligned}
$$

Berdasarkan hasil interval kelas di atas, maka kriteria kelayakan media pembelajaran virtual laboratory oleh pakar dapat dilihat pada Tabel 1.

Tabel 1. Kriteria penilaian oleh

\begin{tabular}{|c|c|c|}
\hline No & $\begin{array}{c}\text { Rentang } \\
\text { Skor }\end{array}$ & Kriteria \\
\hline 1. & $\begin{array}{c}2,33<\text { atau } \\
\leq 3\end{array}$ & $\begin{array}{l}\text { Sangat } \\
\text { Baik }\end{array}$ \\
\hline 2. & $\begin{array}{c}1,65<\text { atau } \\
\leq 2,32\end{array}$ & Baik \\
\hline 3. & $\begin{array}{c}0,97<\text { atau } \\
\leq 1,64\end{array}$ & $\begin{array}{l}\text { Kurang } \\
\text { Baik }\end{array}$ \\
\hline 4. & $\begin{array}{c}0,29<\text { atau } \\
\leq 0,96\end{array}$ & Tidak Baik \\
\hline
\end{tabular}
pakar

nilai tanggapan guru dan siswa terhadap media pembelajaran virtual laboratory.

Tabel 2. Kriteria nilai tanggapan

\begin{tabular}{|c|c|c|}
\hline No & $\begin{array}{c}\text { Rentang } \\
\text { Skor }\end{array}$ & Krit \\
\hline & $\begin{array}{c}3,25<\text { atau } \\
\leq 4\end{array}$ & $\begin{array}{l}\text { Sangat } \\
\text { Mendukung }\end{array}$ \\
\hline & $\begin{array}{c}2,50<\text { atau } \\
\leq 3,25\end{array}$ & Mendukung \\
\hline & $\begin{array}{c}1,75<\text { atau } \\
\leq 2,50\end{array}$ & $\begin{array}{l}\text { Kurang } \\
\text { Mendukung }\end{array}$ \\
\hline & $\begin{array}{c}1<\text { atau } \leq \\
1,75\end{array}$ & $\begin{array}{l}\text { Tidak } \\
\text { Mendukung }\end{array}$ \\
\hline 1 & $\begin{array}{l}\text { Dimodifikasi } \\
\text { Berdasarkan } \\
\text { diperoleh } \\
\text { ntase tangga } \\
\text { n rumus seba }\end{array}$ & $\begin{array}{l}\text { dari Yamasari } \\
\text { hasil kriteria } \\
\text { naka dihitung } \\
\text { pan responden } \\
\text { agai berikut. }\end{array}$ \\
\hline
\end{tabular}
guru dan siswa
Keterangan:

$\mathrm{P}=$ angka persentasen

$\mathrm{n}=$ skor riil

$\mathrm{N}=$ skor total

\section{HASIL DAN PEMBAHASAN}

Hasil Pengembangan

Produk hasil pengembangan laboratorium virtual berbasis smartphone android pada materi laju reaksi untuk siswa kelas XI SMA/MA memiliki format APK. Aplikasi tersebut diberi nama Virtual Lab. Media pembelajaran Virtual lab yang dihasilkan dapat dioperasikan tanpa harus menjalankan simulasi praktikum yang ada secara berurutan (nonlinier). Namun, untuk memahami materipraktikum laju reaksi secara menyeluruh siswa diharapkan untuk menggunakan aplikasi virtual lab setelah menjalankan simulasi praktikum secara berurutan(linier).

Aplikasi virtual lab yang dihasilkan memiliki delapan bagian. Tiap bagian dalam aplikasi memilki kegunaan masing-masing. Berikut adalah tampilan setiap bagian dalam aplikasi virtual lab. Bagian pertama adalah Halaman awal yakni halaman menu utama. Menu utama terdiri atas dua pilihan yaitu pilihan masuk atau keluar. Tampilan halaman menu utama dan halaman mulai seperti pada gambar 1 . 

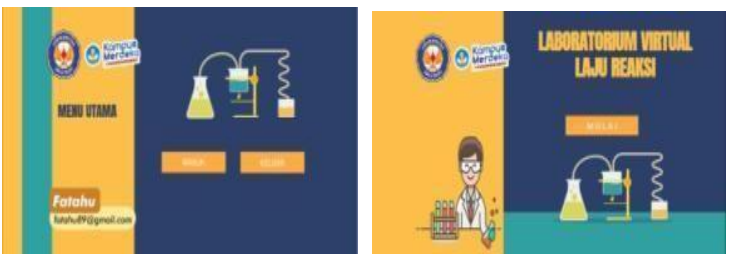

Gambar 1. Halaman Menu utama dan Mulai

Bagian selanjutnya adalah halaman petunjuk dan aturan pemakaian aplikasi Virtual Lab. Halaman pilihan praktikum berisi sajian pilihan praktikum terkait laju reaksi yang akan dilakukan. Tampilan halaman pilihan praktikum seperti pada Gambar 2 .
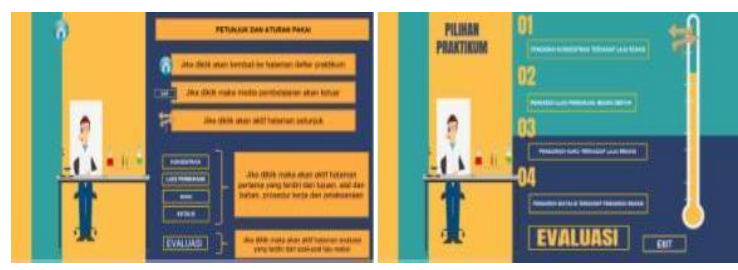

Gambar

2. Halaman

Petunjuk dan Pilihan Praktikum

Bagian selanjutnya adalah Halaman praktikum yang menampilkan menu tujuan, alat dan bahan, prosedur kerja dan pelaksanaan. Tampilan halaman praktikum serta bagian-bagiannya diberikan pada Gambar 3.

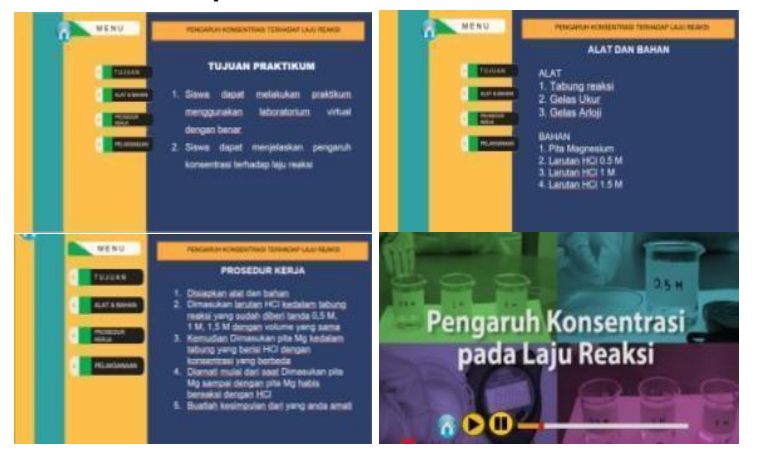

Gambar 3. Halaman Praktikum
Bagian terakhir adalah halaman evaluasi laju reaksi yang berisi soal-soal latihan setelah melihat pelaksanaan praktikum melalui aplikasi Virtual Lab. Tampilan halaman evaluasi laju reaksi seperti pada gambar 4 .

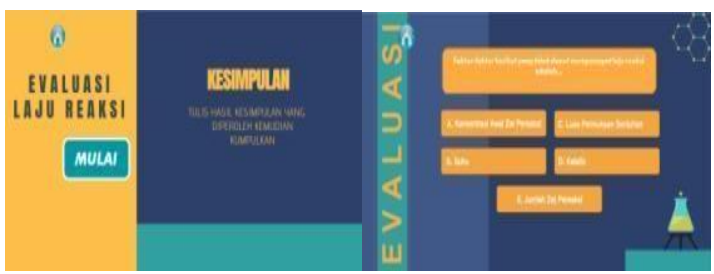

Gambar 4. Halaman Evaluasi

\section{Hasil Uji Coba Terbatas}

1) Hasil uji coba terbatas Terhadap Guru

Peneliti melakukan uji coba terbatas di MAN 1 Kendari dalam penggunaan aplikasi Virtual Lab melalui angket tanggapan guru. Hasil penilaian guru terhadap virtual lab hasil pengembangan dapat dilihat pada Tabel 3. 
Tabel 3. Rekapitulasi tanggapan guru pada uji coba terbatas

\begin{tabular}{cclcc}
\hline No & \multicolumn{1}{c}{ Skor } & \multicolumn{1}{c}{ Kriteria } & $\begin{array}{c}\text { Jumlah } \\
\text { Responden }\end{array}$ & Persentase \\
\hline 1 & $3,25<$ atau $\leq 4$ & $\begin{array}{l}\text { Sangat } \\
\text { Mendukung }\end{array}$ & 1 & $50 \%$ \\
\hline 2 & $2,50<$ atau $\leq 3,25$ & Mendukung & 1 & $50 \%$ \\
\hline 3 & $1,75<$ atau $\leq 2,50$ & $\begin{array}{l}\text { Kurang } \\
\text { Mendukung }\end{array}$ & 0 & $0 \%$ \\
\hline 4 & $1<$ atau $\leq 1,75$ & $\begin{array}{l}\text { Tidak } \\
\text { Mendukung }\end{array}$ & 0 & $0 \%$ \\
\hline
\end{tabular}

2) Hasil uji coba terbatas Terhadap Siswa

Uji coba terbatas juga dilakukan pada 20 orang siswa di MAN 1 Kendari. Rata-rata persentase tanggapan siswa pada aspek kemudahan penggunaan aplikasi virtual lab sebesar $85 \%$ dengan kriteria sangat mendukung dan $15 \%$ dengan kriteria mendukung. Berdasarka n Persentase siswa yang memberi tanggapan "sangat mendukung" tabel 4. adalah $85 \%$ dan $15 \%$ "mendukung" terhadap media pembelajaran berupa aplikasi virtual laboratory. Jumlah responden dengan tanggapan "sangat mendukung" lebih besar dibanding responden dengan tanggapan "mendukung". Hal ini menunjukkan bahwa media pembelajaran virtual laboratory diterima dengan baik karena mencapai skor $\geq 2,51$. Rekapitulasi tanggapan siswa pada uji coba terbatas dapat dilihat pada

Tabel 4. Rekapitulasi tanggapan siswa pada uji coba terbatas

\begin{tabular}{ccccc}
\hline No. & Skor & Kriteria & $\begin{array}{c}\text { Jumlah } \\
\text { Responden }\end{array}$ & Persentase \\
\hline 1 & $3,25<$ atau $\leq 4$ & $\begin{array}{l}\text { Sangat } \\
\text { Mendukung }\end{array}$ & 17 & $85 \%$ \\
\hline 2 & $2,50<$ atau $\leq 3,25$ Mendukung & 3 & $15 \%$ \\
\hline 3 & $1,75<$ atau $\leq 2,50$ Kurang \\
Mendukung & 0 & $0 \%$ \\
\hline 4 & $1<$ atau $\leq 1,75$ & $\begin{array}{l}\text { Tidak } \\
\text { Mendukung }\end{array}$ & 0 & $0 \%$ \\
\hline
\end{tabular}

JPKim FKIP UHO, Vol.6, No.3, Desember 2021| Hal. 214 


\section{Pembahasan}

Aplikasi Virtual Lab merupakan hasil pengembangan dari penelitian ini. Aplikasi Virtual Lab berisi materi tentang praktikum faktor-faktor yang mempengaruhi laju reaksi. Proses pengembangan aplikasi virtuallab telah melalui beberapa tahapan diantaranya tahap penyelidikan dan pengumpulan data, tahap perencanaan yang menghasilkan rancangan produk aplikasi virtual lab yang sesuai dengan kebutuhan serta tahap pengembangan produk virtual lab. Pengembangan aplikasi virtual lab dilakukan untuk mengatasi ketidakefektifan masalah dilaboratorium praktikum keterbatasan alat dan bahan dalam pelaksanaan kegiatan praktikum kimia di sekolah. Produk aplikasi virtual lab ini diharapkan dapat memudahkan siswa melakukan praktikum dan meningkatkan minat belajar siswa dalam mengikuti proses pembelajaran laju reaksi baik itu di kelas maupun di laboratorium.

Hasil uji coba skala terbatas yang dilakukan pada siswa kelas XI jurusan IPA di MAN 1 Kendari menunjukkan bahwa aplikasi virtual lab diterima baik oleh siswa dengan capaian indikator keberterimaan sebesar $\geq 2,51$ dengan tetap memperhatikan beberapa kekurangan yang harus diperbaiki. Respon siswa dalam uji coba terbatasa ditinjau dari beberapa aspek yang bertujuan untuk mengetahui ketertarikan siswa, kesesuaian konten dan kemudahan penggunaan media pembelajaran aplikasi virtual lab. Kategori sangat mendukung didapatkan dari hasil tanggapan siswa terhadap media pembelajaran virtual lab yang dikembangkan sehingga dapat disimpulkan bahwa aplikasi virtual lab hasil pengembangan penelitian ini layak digunakan.

Berdasarkan hasil angket respon siswa diperoleh persentase rata- rata sebesar 3,5 dengan kategori sangat mendukung. Hal ini menunjukkan bahwa media pembelajaran virtual lab tergolong sangat praktis jika diterapkan dalam proses belajar mengajar karena mampu menarik perhatian siswa, konten yang disajikan sesuai dengan konsep materi dan memudahkan siswa mengoperasikan aplikasi virtual lab dalam proses belajar mengajar.

\section{KESIMPULAN}

Persentase tingkat persepsi kuantitatif siswa terhadap penggunaan virtual lab hasil pengembangan berdasarkan hasil uji coba sebesar $85 \%$ sangat mendukung tingkat kelayakan produk untuk menjadi sebuah media pembelajaran materi laju reaksi menggunakan metode praktikum. Keunggulan produk aplikasi virtual lab hasil pengembangan antara lain: (1) aplikasi virtual lab dilengkapi dengan informasi awal seputar praktikum yang akan dilakukan, seperti tujuan, alat dan bahan 
serta prosedur kerja dari praktikum yang akan dilaksanakan. Hal ini berfungsi untuk menunjang kesiapan siswa terkait materi yang akan dipraktikumkan; serta (2) aplikasi virtual lab dapat digunakan secara linier atau nonlinier dengan memilih praktikum yang ingin disimulasikan; (4) efisiensi alat, bahan dan waktu praktikum. Kelemahan aplikasi virtual lab hasil pengembangan antara lain:

(1) aplikasi virtual lab hanya dapat dijalankan secara maksimal pada smartphone berbasis android; (2) ketajaman warna yang ditampilkan pada aplikasi virtual lab tergantung resolusi/kerapatan pixel smartphone yang digunakan.

DAFTAR PUSTAKA

Arif S. Sadiman. 2007. Media Pendidikan: Pengertian, Pengembangan dan Pemanfaatannya, Jakarta:PT Raja Grvindo Persada. h. 7.

Amry, U. W., 2013. Pengembangan Multimedia Pembelajaran Praktikum Titrasi Asam Basa. Skripsi tidak diterbitkan. Malang: FMIPA UM.

Arsyad, A., 2014. Media Pembelajaran.

Jakarta:Rajawali Pers.

Azhar Arsyad, 2011. Media Pembelajaran. Jakarta: Raja Grafindo Persada, h.4.
Cambridge Advanced Learner's Dictionary, Cambridge University Press, Singapore: 2008, h.799.

CengizTuysuz, 2010. The Effect Of The Virtual Laboratory on Students Achievement and Attitudein Chemistry. International Online Journal of Educational Sciences, 2(1) ,h.48.

Chao, L. 2012. Deployment of mobile learning course materials to android powered mobile devices. International Journal of DistanceEducation Technologies, 10(3),116.DOI: $10.4018 /$ jdet. 201207 0101.

Dalgarno,B.,2009. Effectiveness of a Virtuallaboratory as a preparatory resource for distance education chemistry students. Computers \& Education, 53(3), 853865.DOI: $10.1016 /$ j.comped u.2009.05.005.

Fityan. Pembelajaran Berbasis Komputer. Diakses tanggal 10 Oktober 2017. Tersedia Online:http://blog.uinmalang.ac.id/fityanku/pemb elajaran-berbasiskomputers.

Hawkins, I. \& Phelps, A. J. 2013. Virtual laboratory vs. traditional laboratory: which is moreeffective for teaching electrochemistry? Chemistry Education Research and 
Practice, 14, 516523.DOI: $10.1039 / \mathrm{c3rp00070}$ b.

Herga, N. R. 2016. Virtual laboratory in the roleof dynamic visualisation for better understanding of chemistry inprimary school. International Journal of Mathematics, Science \& Technology Education, 3(12),593-608.

J. I. Bintaro and T. Kusir, "Penerapan E- Learning Di Perguruan Tinggi Santi Maudiarti Sekolah Tinggi Pariwisata Trisakti," 32(1), pp. 53-68, 2018.

Lee, W.W. \& Owens, D.L. 2004. Multimedi-BasedInstructional Design, Second Edition. San Fransisco:Pfeiffer.

Lutfi, A. 2017. Pengembangan Media Laboratorium Virtual Bersarana Komputer untuk Melatih Berpikir Kritis pada Pembelajaran Asam, Basa, dan Garam. JPPMS, 1(1), 2633.Darihttp://journal.unes a.ac.id/index.php/jppms.

Martinez-Jimenez, P., PontesPedrajas, A., Polo, J., \& Climent-Bellido, M. S., 2003. Learning in chemistry with virtual laboratories. Journal of Chemical Education, 80(3).

N. Hikmah, N. Saridewi, and S. Agung, 2017. Penerapan Laboratorium Virtual untuk
Meningkatkan Pemahaman Konsep Siswa. EduChemia (Jurnal Kim. dan Pendidikan). 2(2), p. 186.

Pavol Federl and Przemyslaw Prusinkiewicz, "Virtual

Laboratory: an Interactive Software Environment for Computer Graphics". Diakses 10 Oktober 2017.Tersedia: http:pages.cpsc.ucalgary.ca/ federl/Publication/VLABCG19 9/main98.pdf.

Purwanti Widhy. Perangkat dan Media Pembelajaran IPA Untuk Meningkatkan Kualitas Pembelajaran diEra Baru,diakses: tanggal 25 November 2017.

Rahayu, S., Chandrasegaran, A.L., Treagust, D.F., Kita, M., \& Ibnu, S. 2011. Understanding acid-base concepts: Evaluating the efficacy of a senior high school student-centred instructional program in Indonesia. International Journal of Science and Mathematics Education, 9(6),1439-1458. DOI :10.1007/s10763-010-9272$\mathrm{x}$.

Sami Sahin. Computer Simulation In Science Education: Implication for distance education. Turkish Online Journal of Distance Education-TOJDE Juli ISSN 1302-6488, 7(4).

Article:12,h.133. diakses: 
tanggal $\quad 10 \quad$ Oktober 2017.http://todje.anadolu.e du.tr./todje24/pdf/artikel12. pdf.

Tarwiyah, I. 2014. Pengembangan Simulasi Virtual Laboratory Larutan Asam-Basa untuk Membangun Konsep dan Keterampilan Proses Sains. Tesis tidak diterbitkan. Bandung:FMIPAUPI.

Tatli, Z. \& Ayas, A. 2010. Virtual laboratory applications in chemistry education. Procedia Social and Behavioral Sciences, 9, 938942.DOI: $10.1016 /$ j.sbspro. 20 10.12.263.

Woodfield, B. F., Andrus, M. B., Andersen, T., Miller, J., Simmons, B., Stanger, R. 2005.The virtual chem lab project: A realistic and sophisticated simulation of organic synthesis and organic qualitative analysis. Journal of Chemical Education, 82(11).

Wu, Y. T. 2013. Research trend sintechnological pedagogical content knowledge (TPACK) research: Areview of empirical studies published inselected journals from 2002 to 2011. British Journal of Educational Technology, 44(3). pp. E73- E76. https://doi.org/10.1111/j.14 67- 8535.2012.01349.x.
Yudi Munadi. Media Pembelajaran: Sebuah Pendekatan Baru. (Ciputat: Gaung Persad Press, 2008), h.6.

Yusuf, I., Widyaningsih, S. W., \& Purwati, D. 2015. Pengembangan Perangkat Pembelajaran Fisika Modern Berbasis Media Laboratorium Virtual Berdasarkan Paradigma Pembelajaran Abad 21 Dan Kurikulum $2013 . \quad J u r n a l$ Pancaran Pendidikan, 4(2). 